\title{
Trace Element Concentrations in Tree Leaves and Lichen Collected Along a Metal Pollution Gradient Near Olkusz (Southern Poland)
}

\author{
Marta Zakrzewska ${ }^{1}$ - Beata Klimek ${ }^{1}$
}

Received: 25 June 2017 / Accepted: 18 November 2017 / Published online: 27 November 2017

(C) The Author(s) 2017. This article is an open access publication

\begin{abstract}
The aim of the study was to assess the metal pollution in the vicinity of the Bukowno smelter near Olkusz in southern Poland. Birch and oak leaves, pine needles and a lichen Hypogymnia physodes, overgrowing pine bark were collected at stands at different distances from the smelter and analysed for cadmium $(\mathrm{Cd})$, copper $(\mathrm{Cu})$, lead $(\mathrm{Pb})$ and zinc $(\mathrm{Zn})$ content. Concentrations of metals in the lichen were usually higher than in the tree leaves/needles and decreased with distance from the smelter, apart from the $\mathrm{Cu}$ content. The strongest correlation was noticed between $\mathrm{Cd}$ and $\mathrm{Pb}$ concentrations, which indicates a common pollution source (the smelter). Our results show that birch leaves can be potentially useful as a bioindicator of $\mathrm{Zn}$ air pollution since this species was shown to accumulate high amounts of zinc, related to environmental pollution with that metal, in their leaves.
\end{abstract}

Keywords Air pollution · Atomic absorption spectrometry (ASA) $\cdot$ Bioindicator $\cdot$ Environmental monitoring $\cdot$ Hypogymnia physodes

Industrial heavy metal pollution has become a serious environmental problem all over the world. Monitoring of metal pollution levels in the air, soil and water is commonly complemented with biological monitoring, consisting of the measuring of metal content in living organisms. One of the most widespread monitoring organisms are lichens - slow-growing associations of fungi and green algae or cyanobacteria (Latkowska et al. 2005). Lichens are known to accumulate some airborne pollutants by both wet and dry deposition (Nash 1996; Asplund et al. 2015). Lichens are excellent model organisms for the environmental monitoring of air metal pollution on account of their relative resistance to metal pollution and their ability to accumulate metals both from the ground and directly from the air (Sawicka-Kapusta et al. 2010; Kularatne and de Freitas 2013; Will-Wolf et al. 2017). Accumulated trace metals do not interfere noticeably with the lichens' cellular processes, so these organisms are widely used in mapping spatial and temporal patterns of trace metal fallout (Klimek et al. 2015; Węgrzyn et al. 2016).

Beata Klimek

beata.klimek@uj.edu.pl

1 Faculty of Biology and Earth Sciences, Institute of Environmental Sciences, Jagiellonian University, Gronostajowa 7, 30-387 Kraków, Poland
However, lichens are sensitive to sulphur dioxide causing the most visible consequences, referred to as lichen deserts, which occur in cities and industrial regions throughout much of the world (Lisowska 2011). Such a state may make the use of lichens as bioindicators difficult or even impossible in some of the most polluted areas, e.g. those located close to industrial plants. In fact, the majority of regions of high industrialisation and urbanisation are polluted with multiple substances, often including both metals and sulphur oxides.

Upper Silesia in southern Poland is one of the most contaminated areas of Europe and is often referred to as an area of ecological disaster (Pawlowski 1990). Metal ore deposits and intensive mining and smelting have resulted in high metal contents in environment components, achieving values as high as $5437 \mathrm{mg} \mathrm{kg}^{-1}$ soil dry weight (DW) of total zinc concentration, $1877 \mathrm{mg} \mathrm{kg}^{-1}$ soil DW of lead and $57 \mathrm{mg} \mathrm{kg}^{-1}$ soil DW of cadmium (Klimek 2012; Klimek et al. 2016). These values exceed the values accepted by a Polish regulation as non-harmful several times over.

Lichens are known to be excellent indicators of air pollution whereas plants, including trees, absorb metals from both the air and soil through foliar and root uptake (Kozlov et al. 1995; Shahid et al. 2017). Therefore, the metal contents in lichens and tree leaves/needles collected in these same places may differ significantly. As such, the authors assume 
that common plant species can be used for environmental monitoring in such areas as long as the metal concentration in the measured organisms will be related to environment pollution, which is the most essential feature of any model bioindicator.

The aim of this study was to assess current trace metal pollution in the Olkusz region using the lichen Hypogymnia physodes, a widely used bioindicator, as well as selected tree species that are common to the region - silver birch Betula pendula, sessile oak Quercus robur and Scots pine Pinus sylvestris. We were searching for the tree species that follow the pattern of metal concentration in lichen, and therefore would be potentially useful as bioindicators of air pollution in heavily polluted areas.

\section{Materials and Methods}

The samples of lichen, leaves of birch and oak and pine needles were collected along a metal pollution gradient near Olkusz in southern Poland in the vicinity of the former zinc and lead smelter. Mining and smelting activity have been recorded here since the Middle Ages and large-scale industry in the Olkusz region started in the 1970s. The samples were collected on forest stands located $2.5-12 \mathrm{~km}$ from the Bukowno smelter, that is between $50^{\circ} 16^{\prime}$ and $50^{\circ} 45^{\prime} \mathrm{N}$ and $19^{\circ} 37^{\prime}-18^{\circ} 39^{\prime} \mathrm{E}$. The pollution level in the region is well known based on several earlier studies (Laskowski and Maryański 1993; Niklińska et al. 2006; Hrdlička and Kula 2011; Klimek et al. 2016). The relatively short gradient was established (up to $12 \mathrm{~km}$ from the smelter) towards the west (the main wind direction and air pollutants transportation). The samples were collected during 1 day in December 2014.

Each lichen sample was composed of lichen collected from the bark of a neighbouring few pine trees ( $P$. sylvestris L.) using a knife and mixed in a single bag. All the samples were collected from pine as tree species differ in elemental composition, which affects the element composition in lichen thalli (Asplund et al. 2015). The leaves of silver birch $B$. pendula Roth. and sessile oak $Q$. robur as well as the needles of Scots pine $P$. sylvestris L. were collected from the west side of a few neighbouring trees. In total, 72 samples of lichen and 108 samples of tree leaves or needles were collected.

The samples were transported to the laboratory in bags. Then, the samples were purged to remove any bark or dust particles, crumbled and dried at $60^{\circ} \mathrm{C}$ for 5 days to achieve a constant mass (dry weight, DW). The total concentrations of the metals $(\mathrm{Cd}, \mathrm{Cu}, \mathrm{Pb}, \mathrm{Zn})$ in each sample were determined after wet digestion of $0.5 \mathrm{~g}$ of DW of sample in $10 \mathrm{~mL}$ of SupraPure-concentrated $\mathrm{HNO}_{3}$ and $\mathrm{HClO}_{4}$ (4:1 v/v) (Sigma-Aldrich) (Klimek et al. 2015). The metal concentrations in the digests were measured using atomic absorption spectrometry (AAS) with a flame or graphite furnace nebuliser (Perkin-Elmer). To control for efficiency of the digestion, purity of the chemicals and glassware, and precision of the analytical equipment, five blank samples and five replicates of standard certified reference material were processed along with the lichen samples (Trace elements in lichen, CRM $^{\circledR}-482$; IRMM, Geel, Belgium) (Klimek et al. 2015). Each analysis was performed in two replicates and the data were averaged and expressed based on the DW of the sample. The detection limits were determined according Perkin-Elmer guidelines, that is after multiple metal analysis of deionised water being zero concentration of calibration curve and then calculation for the mean value with its triple standard deviation.

The normality criterion for data distribution within groups was checked with the Shapiro-Wilk test and the data were transformed when necessary. The General Linear Model was used to test for the differences in mean values of metal concentrations in the lichen and tree leaves/needles (categorical factor), and to test for the effect of distance from the smelter (quantitative factor) and for interaction between the two $(p<0.05)$. In cases where the interaction was not significant, it was removed from the model. A Comparison of Regression Lines was used to find differences in the slopes between the studied sample type (lichen and tree species) $(p<0.05)$. Correlation analysis was used to test the relationships between the concentrations of the studied metals, and Pearson's correlation coefficients were considered significant at $p<0.05$. Clustering method, a method based on nearest neighbour with squared Euclidean distance, was used to detect similarity pattern in metal concentrations in the lichen and leaves/needles that could possibly indicate a common source of pollution. All statistical analyses were performed using the Statgraphics Centurion XVII (StatPoint Technologies Inc., Warrenton, VA, USA).

\section{Results and Discussion}

The detection limits for the analytical methods used were $0.02,0.04,0.36$ and $8.75 \mathrm{mg} \mathrm{kg}^{-1}$ for $\mathrm{Cd}, \mathrm{Cu}, \mathrm{Pb}$ and $\mathrm{Zn}$, respectively. Metal recoveries were $99 \%, 94 \%, 93 \%$ and $99 \%$ for $\mathrm{Cd}, \mathrm{Cu}, \mathrm{Pb}$ and $\mathrm{Zn}$, respectively. For each metal the GLM model was highly significant $(p<0.0001)$ (Table 1). The lichen and tree leaves/needles differed in each metal content, whereas the metal content in the collected material decreased with distance from the smelter for $\mathrm{Cd}, \mathrm{Pb}$ and $\mathrm{Zn}$, but the distance effect was not significant for $\mathrm{Cu}$ (Table 1). The only significant interaction between species and distance from the smelter was found for $\mathrm{Pb}$ (Table 1), which suggests strong differences between the species in $\mathrm{Pb}$ accumulation along the pollution gradient. 
Differences in mean metal concentrations between species were found for each element despite the relatively high variance in the data; significantly higher $\mathrm{Cd}$ and $\mathrm{Pb}$ concentrations were found in the lichen thalli compared to the tree leaves/needles (Table 2). The concentrations of $\mathrm{Zn}$ were similarly high in the lichen thalli and birch leaves compared to the other two species (Table 2). In turn, the highest concentrations of $\mathrm{Cu}$ were found in the oak leaves (Table 2).

The Comparison of Regression lines analysis indicated that $\mathrm{Pb}$ concentration decreased with distance from the smelter especially in the lichen, whereas it did change greatly in the tree leaves/needles along the metal pollution gradient (Fig. 1). For the other metals, the decrease in their concentration with distance from the smelter was similar for all the studied species (data not shown).

The $\mathrm{Cd}$ and $\mathrm{Pb}$ exhibited a similar pattern in their concentrations in the collected samples as shown by the cluster analysis (Fig. 2). These included the highest metal content in the lichen and a much lower content in the tree leaves/ needles, especially in the oak leaves (Table 2). The Zn concentration pattern was slightly different from $\mathrm{Cd}$ and $\mathrm{Pb}$, as the highest metal content was found both in the lichen and birch (Fig. 1; Table 2). In turn, the $\mathrm{Cu}$ concentration pattern differed from all the others (Fig. 2), which resulted from the lower $\mathrm{Cu}$ content in the lichen than in the oak leaves and a lack of effect of distance from the smelter (Tables 1,2). All this indicates that $\mathrm{Cu}$ sources in the collected material were other than from the smelter. In fact, metal ores in the Upper Silesia Industrial region contain zinc, lead and cadmium but not copper and, moreover, copper ores are not processed in the region.

Our results indicate that birch leaves can be potentially useful as a bioindicator of $\mathrm{Zn}$ pollution since this species was shown to accumulate high amounts of $\mathrm{Zn}$ in their leaves,
Table 1 GLM parameters for metal concentrations in lichen thalli and tree leaves/needles collected along the pollution gradient near the smelter
Table 2 Trace metal concentrations $\left(\mathrm{mg} \mathrm{kg}^{-1} \mathrm{DW}\right)$ in lichen thalli and tree leaves/ needles collected in the studied sites; mean values $( \pm$ standard deviation; $\mathrm{n}=18$ for the lichen or $\mathrm{n}=9$ for the leaves/needles)
Fig. 1 A comparison of regression lines for the $\mathrm{Pb}$ content in the lichen and tree leaves/ needles and its relation to the distance from the smelter (intercepts $p<0.0001$, slopes $p=0.0088$ )

\begin{tabular}{lllll}
\hline & Metal & & & \\
\cline { 2 - 5 } & $\mathrm{Cd}$ & $\mathrm{Cu}$ & $\mathrm{Pb}$ & $\mathrm{Zn}$ \\
\hline Model; $p$ value & $<0.0001$ & $<0.0001$ & $<0.0001$ & $<0.0001$ \\
Model; $\mathrm{R}_{\text {adj }}^{2}(\%)$ & 72.6 & 46.6 & 83.2 & 55.4 \\
Factor: species (lichen or trees); $p$ value & $<0.0001$ & $<0.0001$ & $<0.0001$ & $<0.0001$ \\
Factor: distance from smelter; $p$ value & 0.0027 & 0.2441 & 0.0010 & 0.0001 \\
Interaction species x distance; $p$ value & $\mathrm{ns}$ & $\mathrm{ns}$ & 0.0088 & $\mathrm{~ns}$ \\
\hline
\end{tabular}

\begin{tabular}{llccc}
\hline Species & \multicolumn{4}{l}{ Metal concentration $\left(\mathrm{mg} \mathrm{kg}^{-1} \mathrm{DW}\right)$} \\
\cline { 2 - 5 } & $\mathrm{Cd}$ & $\mathrm{Cu}$ & $\mathrm{Pb}$ & $\mathrm{Zn}$ \\
\hline Lichen & $3.16^{\mathbf{c}}( \pm 2.40)$ & $8.47^{\mathbf{b}}( \pm 2.07)$ & $51.47^{\mathbf{b}}( \pm 62.76)$ & $470.8^{\mathbf{b}}( \pm 286.3)$ \\
Birch & $0.56^{\mathbf{b}}( \pm 0.30)$ & $5.89^{\mathbf{a b}}( \pm 1.67)$ & $2.48^{\mathbf{a}}( \pm 2.11)$ & $761.1^{\mathbf{b}}( \pm 532.9)$ \\
Oak & $0.17^{\mathbf{a}}( \pm 0.14)$ & $14.4^{\mathbf{c}}( \pm 8.06)$ & $2.15^{\mathbf{a}}( \pm 0.71)$ & $196.2^{\mathbf{a}}( \pm 243.8)$ \\
Pine & $0.64^{\mathbf{b}}( \pm 0.74)$ & $4.82^{\mathbf{a}}( \pm 2.62)$ & $2.21^{\mathbf{a}}( \pm 1.18)$ & $229.2^{\mathbf{a}}( \pm 205.4)$ \\
\hline
\end{tabular}

Results of GLM analysis: differences between materials (columns) are indicated with different bold letters in superscript $(\mathrm{a}-\mathrm{c})$

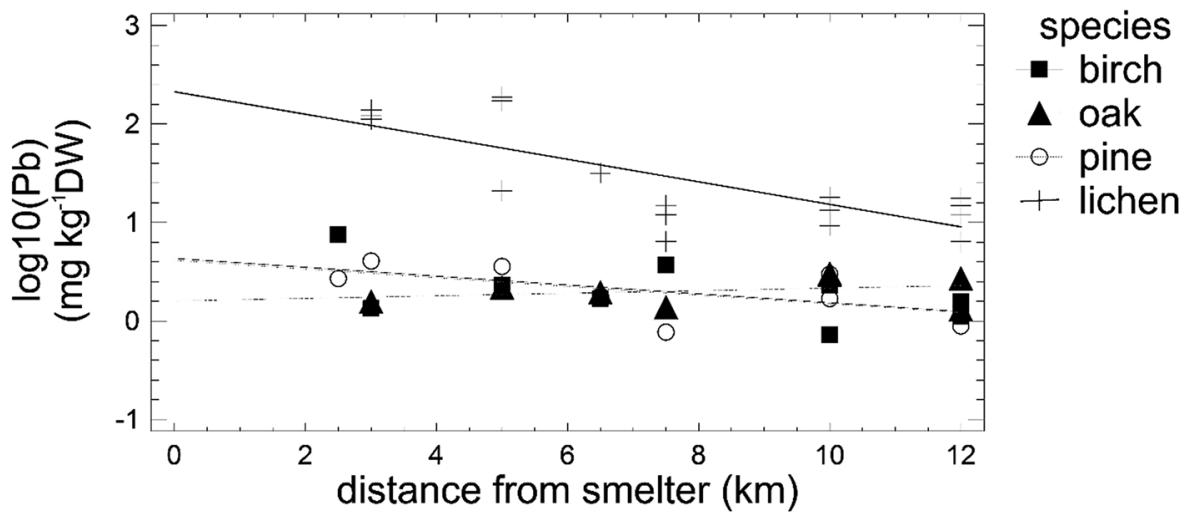




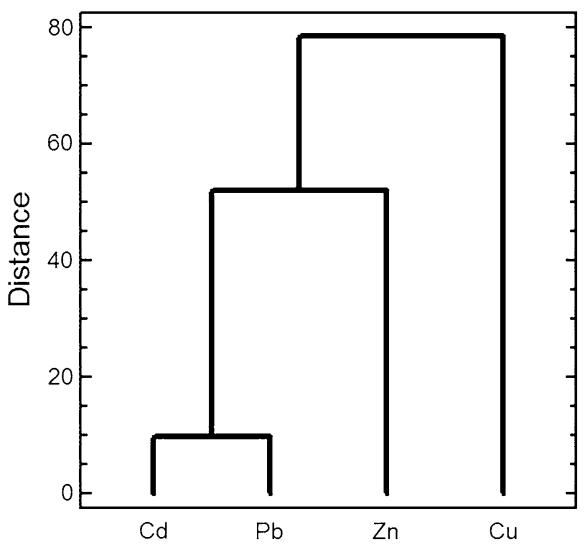

Fig. 2 Dendrogram presenting the similarity between metal concentrations $(\mathrm{Cd}, \mathrm{Cu}, \mathrm{Pb}, \mathrm{Zn})$ in the lichen and studied tree leaves/needles

which is related to environmental pollution from that metal. In our study we found $\mathrm{Zn}$ concentration in the birch leaves reached as high a value as $1866 \mathrm{mg} \mathrm{kg}^{-1} \mathrm{DW}$ in the closest vicinity of the metal smelter. This result is similar to the $1640 \mathrm{mg} \mathrm{kg}^{-1}$ DW obtained there previously by Hrdlička and Kula (2011). Birch resistance to pollution makes it a possible bioindicator in environmental studies because it survives even within wastelands (Kozlov et al. 1995). Soil $\mathrm{pH}$ can influence the solubility of metals, and metal contamination typically reduces soil pH (Speir et al. 1999; Boivin et al. 2006). Birch has been found to raise soil pH (Priha and Smolander 1999) and this may support soil microorganisms that protect the tree against metals contamination. Compared to other tree species, birch tends to accumulate $\mathrm{Zn}$ even in regions unpolluted or moderately polluted with metals (Kosiorek et al. 2016). Since $\mathrm{Zn}$ is a microelement this means that in some doses it is beneficial for organisms, including plants (Kozlov et al. 1995; Shahid et al. 2017).

In addition, we found that birch and pine can be used potentially as bioindicators for $\mathrm{Cd}$. However, Cd concentrations in birch leaves and pine needles are much lower than those in lichens. This may generate problems with low correctness of metal analysis and small differences between polluted and unpolluted locations. In the case of $\mathrm{Pb}$, we showed definitively that only lichens can serve as air quality indicators of $\mathrm{Pb}$ pollution.

Acknowledgements This study was supported by funds from Jagiellonian University (subsidy WBiNoZ/INoS/DS759). We thank the Forestry Management in Olkusz for scientific collaboration.

Open Access This article is distributed under the terms of the Creative Commons Attribution 4.0 International License (http://creativecommons.org/licenses/by/4.0/), which permits unrestricted use, distribution, and reproduction in any medium, provided you give appropriate credit to the original author(s) and the source, provide a link to the Creative Commons license, and indicate if changes were made.

\section{References}

Asplund J, Ohlson M, Gauslaa Y (2015) Tree species shape the elemental composition in the lichen Hypogymnia physodes transplanted to pairs of spruce and beech trunks. Fungal Ecol 16:1-5

Boivin MEY, Greve DG, Kools SAE, van der Wurff AWG, Leeflang P, Smit E, Breure AM, Rutgers M, van Straalen NM (2006) Discriminating between effects of metals and natural variables in terrestrial bacterial communities. Appl Soil Ecol 34:103-113

Hrdlička P, Kula E (2011) Changes in element content of birch leaves (Betula pendula Roth) in polluted air. Pol J Environ Stud 20:661-670

Klimek B (2012) Effect of long-term zinc pollution on soil microbial community resistance to repeated contamination. Bull Environ Contam Toxicol 88:617-622

Klimek B, Tarasek A, Hajduk J (2015) Trace element concentrations in lichens collected in the Beskidy Mountains, the Outer Western Carpathians. Bull Environ Contam Toxicol 94:532-536

Klimek B, Sitarz A, Choczyński M, Niklińska M (2016) The effects of heavy metals and total petroleum hydrocarbons on soil bacterial activity and functional diversity in the Upper Silesia industrial region (Poland). Water Air Soil Pollut 227:265-274

Kosiorek M, Modrzewska B, Wyszkowski M (2016) Levels of selected trace elements in Scots pine (Pinus sylvestris L.), silver birch (Betula pendula L.), and Norway maple (Acer platanoides L.) in an urbanized environment. Environ Monit Assess 188:598-611

Kozlov MV, Haukioja E, Bakhtiarov AV, Stroganov DN (1995) Heavy metals in birch leaves around a nickel-copper smelter at Monchegorsk, north-western Russia. Environ Pollut 90:291-299

Kularatne KIA, de Freitas CR (2013) Epiphytic lichens as biomonitors of airborne heavy metal pollution. Environ Exp Bot 88:24-32

Laskowski R, Maryański M (1993) Heavy metals in epigeic fauna: trophic level and physiological hyphothesis. Bull Environ Contam Toxicol 50:232-240

Latkowska E, Bober B, Chrapusta E, Adamski M, Kaminski A, Bialczyk J (2015) Secondary metabolites of the lichen Hypogymnia physodes (L.) Nyl. and their presence in spruce (Picea abies (L.) H. Karst.) bark. Phytochemistry 118:116-123

Lisowska M (2011) Lichen recolonisation in an urban-industrial area of southern Poland as a result of air quality improvement. Environ Monit Assess 179:177-190

Nash TH III (1996) Lichen biology. Cambridge University Press, Cambridge, pp 136-153

Niklińska M, Chodak M, Laskowski R (2006) Pollution-induced community tolerance of microorganisms from forest soil organic layers polluted with $\mathrm{Zn}$ or $\mathrm{Cu}$. Appl Soil Ecol 32:265-272

Pawlowski L (1990) Chemical threat to the environment in Poland. Sci Total Environ 96:1-21

Priha O, Smolander A (1999) Nitrogen transformations in soil under Pinus sylvestris, Picea abies and Betula pendula at two forest sites. Soil Biol Biochem 31:965-977

Sawicka-Kapusta K, Zakrzewska M, Bydłoń G, Hajduk J (2010) Ocena zanieczyszczenia powietrza stacji bazowych ZMŚP metalami ciężkimi i dwutlenkiem siarki w latach 2001-2009 z wykorzystaniem porostu Hypogymnia physodes (Air pollution of monitoring base stations ZMŚP with heavy metals and sulphur dioxide in 2001-2009 using Hypogymnia physodes lichens). Monitor Środowiska Przyrodniczego Kieleckie Towarzystwo Naukowe Kielce 11:63-71 (in Polish)

Shahid M, Dumat C, Khalid S, Schreck E, Xiong T, Niazi KN (2017) Foliar heavy metal uptake, toxicity and detoxification in plants: a comparison of foliar and root metal uptake. J Hazard Mater $325: 36-58$ 
Speir TW, Kettles HA, Percival HJ, Parshotam A (1999) Is soil acidification the cause of biochemical responses when soils are amended with heavy metal salts? Soil Biol Biochem 31:1953-1961

Węgrzyn M, Wietrzyk P, Lisowska M, Klimek B, Nicia P (2016) What influences heavy metals accumulation in arctic lichen Cetrariella delisei in Svalbard? Pol Sci 10:532-540
Will-Wolf S, Jovan S, Amacher MC (2017) Lichen elemental content bioindicators for air quality in upper Midwest, USA: a model for large-scale monitoring. Ecol Indic 78:253-263 